\section{Under the volcano}

SIR - In making a case for the inadequacies of the Japanese government's volcano prediction committee, David Swinbanks (Nature 351, 511; 1991) suggests that the eruption of Mount Unzen, because it was not predicted in advance, resulted in the death of 42 people. But the eruption had been under way for two weeks, the tragic deaths being caused by the avalanching of hot debris from the front of a thick lava dome, perhaps triggered by a small explosion near the summit of the volcano.

This dome had been slowly advancing over the headwall of a steep canyon on the east side of the volcano, and the resulting avalanches had been front-page news in Japan for more than a week before the disaster. Network television channels (I was in Japan at the time) carried spectacular images of hot lava blocks spalling from the oversteepened dome and cartwheeling down the canyon to form pyroclastic flows. The volcanologists and Japanese TV crews who perished knew full well that pyroclastic flows were being triggered. Why else would they have been up there taking pictures? I do not agree that the statements of the Japanese prediction committee were connected in any way with their demise. In confusing the difference between predicting eruptions (which is sometimes possible) and predicting the generation of hot avalanches (which is virtually impossible), Swinbanks unfairly blames the Japanese interagency committee because it did not "fully anticipate the particular threat that claimed [42] lives". I believe that no committee could have predicted the magnitude and timing of the 3 June avalanche and resulting deadly pyroclastic flow.

Swinbanks acknowledges that the volcano eruption committee, chaired by Professor Daisuke Shimozuru, did in fact warn that pyroclastic flows were apt to occur. But he chides the committee for not explaining "what a pyroclastic flow is, how deadly it is, or how fast it can strike". Such a statement is simply unfair. Are we to criticize a flood prediction committee for not explicitly warning that rising waters might cause people to drown? People in Japan are well aware of the dangers of pyroclastic flows, thanks to excellent programmes in public understanding of science, as well as the numerous TV newscasts at the time. People did not need an interagency committee to tell them these avalanches are dangerous or that they move fast.

Because the early parts of the eruption took place during Japan's rainy season, swiftly moving mudflows were (and continue to be) a significant hazard at Unzen. No committee or group should be criticized for emphasizing the destructive potential of volcanic mudflows. On 26 May, when it became obvious that parts of the growing lava dome had already become unstable, the Unzen volcano prediction committee stated that pyroclastic flows might also occur. Thousands of people were safely evacuated in the next few days; the only people to perish on 3 June were the 42 individuals, including 15 journalists and 3 volcanologists, who elected to take the risk of entering the restricted zone. It is worth remembering that this zone was established in large part on the basis of statements from the Unzen volcano prediction committee This is a sad and paradoxical story, but not one of inadequate performance by that committee.

Two final points: the inset map accompanying an article by Christopher Anderson on the same page as Swinbanks mistakenly locates Sakura-jima volcano on the Shimabara peninsula, next to to Unzen. Sakura-jima is actually about $140 \mathrm{~km}$ to the south. And the correct spelling of the US Geological Survey researcher cited is Tom Casadevall.

RICHARD S. FISKE

National Museum of Natural History,

Smithsonian Institution,

Washington, DC 20560, USA

SIR - Many volcanologists around the world are dismayed about the disparaging tone of David Swinbanks' News article about volcano prediction by Japanese scientists. Japanese volcanologists are among the world leaders in developing predictive techniques for dealing with threatening volcanoes. In keeping with their well-established tradition, they closely monitored the activity of Unzen volcano throughout the current volcanic crisis, which began in November 1990 , and they have accurately assessed its eruptive potential based on analyses of both the history of the volcano and the characteristics of its new unrest. Their fine performance stands in stark contrast to the astonishing implications in Swinbanks' account.

Despite warnings by Japanese scientists and successful evacuation of vulnerable areas, 42 lives were lost at Unzen in early June in a pyroclastic flow that was considerably larger than those preceding it. Seeking a scapegoat for the tragedy, some journalists, including Swinbanks, identified and blamed the volcano prediction committee. But a more thorough investigation would have revealed that after long dormancy of a volcano (200 years at Unzen), the eventual outcome of renewed unrest is notoriously difficult to predict. Nevertheless, Japanese researchers had correctly assessed the nature of the immediate hazards at Unzen. Further, Japan has developed one of the world's most effective systems of collaboration among the civil government, scientists and law-enforcement and emergency-management agencies for dealing with natural hazards. Their procedures are models for other nations, and these procedures were operating effectively at Unzen.

The people who died so tragically had knowingly entered the clearly designated danger zone, generally for professional reasons: among the victims were three experienced volcanologists who fully understood the hazards that they faced. The deaths cannot and should not be ascribed to any deficiency in the performance of the Japanese volcano advisory committee. Swinbanks expressed surprise that the Japanese public continues to listen to warnings: if, however, local people had failed to heed the warnings at Unzen, without doubt the casualty toll would have been much higher.

Donald W. Peterson (IAVCEI)

\section{Davenport Way}

Palo Alto

California 94306, USA

SWINBANKS REPLIES - I did not say that the volcano prediction committee failed to predict the pyroclastic flow of 3 June. Rather, I argued that the committee failed fully to anticipate the danger of pyroclastic flows and failed to issue adequate public warnings.

The first pyroclastic flows occurred at Unzen on 24 May. But despite the known dangers of such flows, the committee did not comment on them until after a major flow on 26 May. The committee's statement said only: "the occurrence of pyroclastic and mud flows can be expected from now on and a strict alert is necessary".

Fiske argues that pyroclastic flows are a well-known phenomenon in Japan, and thus it was not necessary for the committee to explain their dangers. But pyroclastic flows have not occurred at Unzen for at least 200 years, nor are they common elsewhere in Japan.

After the 3 June tragedy, pyroclastic flow (kasairyu) became a household word in Japan. But in the critical period of late May media coverage of the phenomenon was much more limited. Surely one of the roles of the committee should be to educate the public?

The committee has perhaps opened itself to some undue criticism by calling itself a "prediction" committee. As Professor Shimozuru explains on page 295, volcanic prediction is a bit like "betting". Given the limitations of the science, should not the committee be renamed so as not to raise false expectations in the general public? 